\title{
The nature of work family conflict: A review and agenda for future research
}

\author{
Dr. Navaneethakrishnan Kengatharan \\ University of Jaffna, Sri Lanka \\ Department of Human resource management \\ kenga@jfn.ac.lk
}

Doi:10.5296/ ijhrs.v5i2.7630 URL: http://dx.doi.org/10.5296/ ijhrs.v5i2.7630

\begin{abstract}
The main purpose of this research was to identify gaps in the existing literature on work family conflict from the past 30 years, and develop a viable research plan for further research. Research papers from peer-reviewed journals were collected from multiple databases including Proquest, Business Source Premier (EBSCOhost), Expanded Academic (Gale), Emerald, ISI Web Science, the Sloan Work and Family Research Network at Boston College, and Google Scholar. Full text papers published in English in the last three decades were included in this study. The collected papers were then classified and analysed using thematic content analysis. Factors influencing work family conflict, their consequences and the relevant constructs were systematically identified and summarised. The gaps in the extant literature from the past 30 years were identified and these were subsumed under a regional gap-theoretical cultural perspective, a measurement gap, cross cultural studies, organisational responsiveness, environmental factors and gender role theory. The present study serves as a springboard for future studies and theory building on the interaction between the work and family domains. This research is original in its nature as it has identified major strands of the extant literature on work family conflict and ipso facto it can guide research scholars towards the unknown terrain of the work family sphere. This research urges policy makers, practitioners and members of organisations to digest this knowledge and it aims to make them aware of the overarching area of work and family in the contemporary world. The major limitation of this study is the Tower of Babel Bias, to wit, research studies not published in English were excluded from this study.
\end{abstract}

Keywords: Work to family conflict; family to work conflict; working hours; role theory. 


\section{Introduction}

Work family conflict research addresses the relationship between paid employment and commitment to kin (Drago and Kashian, 2003). That is, it focuses on the difficulties that employees have in balancing their work and family responsibilities (Adams et al., 1996). Greenhaus and Beutell (1985) defined work family conflict as "a form of inter-role conflict in which the role pressures from the work and family domains are mutually incompatible in some respects" (p.77). The subject matter of work family conflict has recently received significant consideration from academics, employers, politicians and the media. Employees in many countries experience a higher level of work family conflict, due to the pressure on their work and family lives than ever before. In recent years, economic and business globalisation has made work / family issues increasingly important, not only in developed, but also in developing countries (Ling and Poweli, 2001). For example, economic factors (e.g., inflation, economic recession, unemployment, and under-employment) and globalisation (e.g., foreign investment flows, multinational companies, and the changing pace of information technology) impact both directly and indirectly on the way in which people live and work. Therefore, research findings in the work family conflict sphere from the past may not hold water today. The issue of work family conflict has received much attention and it is noted as being a particular concern for today's businesses (Grandeyet al., 2005).

From the organisational viewpoint, work family conflict is a deleterious factor for the success and survival of organisations. On the other hand, it seriously affects the family lives of employees. Organisational policies and practice regarding balancing work and family vary from organisation to organisation. Similarly, the way that individuals balance their work and family lives varies depending on factors such as family structure. Thus, many researchers have been looking at work family conflict through multiple lenses. For example, at the beginning, researchers looked at the factors influencing work family conflict, then its consequences, and more recently, the measures that employers use to balance work and family through organisational policies, practices and so on. Although there is a great deal of research on the work and family issue, researchers continue to find gaps and define and redefine related constructs.

Work family conflict is interdisciplinary, ranging across sociology, psychology, organisational behaviour, human development, labour economics, industrial relations, management, demography, and women's studies, but there is a dearth of systematic reviews of the work family conflict literature (Drago and Kashian, 2003). A systematic review of research is 'principally justified by the manner in which the reviewer proceeds, stage by stage, with full transparency and explicitness about what is (and what is not) done, typically using a protocol to guide the process' (Young et al., 2002, p.220). The systematic review has become a legitimate research activity especially in the social sciences (Young et al., 2002) and it is argued that it is much more needed for the social sciences (Nutley, 2003 cited in Bardoel et al., 2008). Thus, carrying out a systematic review of the literature in the work family conflict arena can shed new light on unknown areas of this particular discipline. Examining empirical studies on work family conflict from 1980 until now has been very useful in explaining many relationships between the work and family domains. The main aim of this study is to unearth 
the gaps by reviewing the extant literature and thus, devising a plan for further future investigation. Consequently, it builds a robust knowledge base in the field of work family interference. Therefore, this research is timely and significant to advance the field of work family conflict and contributes to both the creation and the development of knowledge (Drago and Kashian 2003).

\section{Methods}

Research Philosophical stands

One of the research philosophies is the ontological assumption that we make about the 'nature of reality'. It is pivotal for any study, because otherwise, the study is treated as "blinded" (Easterby-Smith et al., 2002, p. 27). This research assumes the ontological belief that the real world is made up of people's experiences of work family conflict, to wit, work family conflict is a reality that people confront in their day-to-day lives. However, the magnitude, causes and outcomes of work family conflict may vary across countries, organisations and peoples. Many researchers accept the idea of multiple realities and this is called 'subjectivism'. According to Blaikie (2007), it is supposed that reality is not independent of individual thought. Researchers' findings are not consistent with each other. Research findings vary in different contexts such as in different locations, in different family structures, and where there are different organisational policies and practices. There will also be differences due to the demographic form of the participants and the methodology used. Thus, in terms of its epistemology, this study adopted an interpretivist approach. Research approach can significantly vary depending on what is to be researched. Since this research is related to a document search (research papers), a thematic content analysis was adopted. Thus the knowledge captured definitely forms a new platform for future research.

Data collection

The initial search strategy generated 2506 journals articles using the search parameters. Of these 2506 articles, almost $21 \%$ of the research papers $(N=535)$ were screened during the last three decades and then analysed. The following criteria were explored in the selection of research papers to be reviewed.

- Published in a peer-reviewed journal between 1980 and the present.

- Full text published in English

- Articles included at least one of the following terms / parameters: work demands and family demands, work family conflict, work to live and live to work, work life balance, working long hours, family and human resource policy, dual earners, work and family, work - non-work/home, work family policies and practices, and work family interferences.

With the help of a web of science search ('Web of science search' covers over 10000 journals and 110000 conference proceedings in over 45 different languages), a voluminous number of research papers were identified in peer-reviewed journals. However, some articles published in a language other than English (German, Czech, Spanish, Serb-Croatian, Finnish, French, 
Italian, Korean, Chinese, and Japanese) were excluded. Some of the articles examined work family conflict in a similar way and their results were consistent with other researchers. Consequently, those that were repeated were also excluded from this selection. The full text of each article was obtained electronically from the following databases: Proquest, Business Source Premier (EBSCOhost), Expanded Academic (Gale), Emerald, ISI Web Science, the Sloan Work and Family Research Network at Boston College, and Google Scholar.

Data analysis

At the outset, the relevant research papers were selected and classified in terms of theme(s) or topic(s). Generally, the theme is the category that is represented in each paper, although Corbin and Strauss (1990) describe selective coding in grounded theory. Themes were generated including: direction of work family conflict, consequences of work family conflict, organisational responsiveness to work family issues, predictors of work family conflict and so on. These themes were identified in terms of reviewing journal articles and they featured across many disciplinary journals including: Journal of Vocational Behavior; Journal of Applied Psychology; Journal of Occupational Health Psychology; Journal of Organizational Behavior; Academy of Management Journal; Gender, Work and Organization; Journal of Occupational and Organizational Psychology; Journal of Family Issues; the International journal of Human Resource Management; Journal of Management; Journal of Business and Psychology; Journal of Marriage and Family; Personnel Psychology; Work employment and society; Human Resource Management; Career Development International; Human Relations; Organizational Behavior and Human Decision Processes; Equal Opportunities International; Journal of Family and Economic Issues; New Zealand Journal of Psychology; Community, Work and Family; International Journal of Stress Management; Women in Management Review; British Journal of Industrial Relations; Construction Management and Economics; British Journal of Management; Administrative Science Quarterly; Group and Organization Management; and Journal of Management Studies.

\section{Results and discussion}

A total of 535 published research papers on work family research were found from 1980 to the present across 30 academic interdisciplinary journals. The academic journals where the most articles appeared were: Journal of Vocational Behavior (106), which yielding 20\%, followed by Journal of Applied Psychology (51), Journal of Occupational Health Psychology (50), Journal of Organizational Behavior (48), Academy of Management Journal (27), and Gender, Work and Organization (26). The first six journals contributed more than $57 \%$ of the research papers on work and family; just $43 \%$ of the research papers were found in the other 29 journals. Table 1 presents a full list of the journals with the number of articles that appeared during the stipulated time period. 


\section{Macrothink \\ International Journal of Human Resource Studies \\ ISSN 2162-3058 \\ 2015, Vol. 5, No. 2}

Table 1: Academic journals in which work family research appeared

\begin{tabular}{|c|c|c|}
\hline Name of the Journal & Number of & $\%$ \\
\hline Journal of Vocational Behavior & 108 & 20 \\
\hline Journal of Applied Psychology & 51 & 9 \\
\hline Journal of Occupational Health Psychology & 50 & 9 \\
\hline Journal of Organizational Behavior ${ }^{\text {a }}$ & 48 & 9 \\
\hline Academy of Management Journal & 27 & 5 \\
\hline Gender, Work and Organization & 26 & 5 \\
\hline Journal of Occupational and Organizational Psychology ${ }^{b}$ & 24 & 4 \\
\hline Journal of Family Issues & 23 & 4 \\
\hline The International journal of Human resource management & 20 & 4 \\
\hline Journal of Management & 17 & 3 \\
\hline Journal of Business and Psychology & 16 & 3 \\
\hline Journal of Marriage and Family & 15 & 3 \\
\hline Personnel Psychology & 13 & 2 \\
\hline Work employment and society & 13 & 2 \\
\hline Human Resource Management & 12 & 2 \\
\hline Career Development International & 11 & 2 \\
\hline Human Relations & 11 & 2 \\
\hline Organizational Behavior and Human Decision Processes & 09 & 2 \\
\hline Equal Opportunities International & 06 & 1 \\
\hline Journal of Family and Economic Issues & 06 & 1 \\
\hline New Zealand Journal of Psychology & 04 & $<1$ \\
\hline Community, Work and Family & 04 & $<1$ \\
\hline International Journal of Stress Management & 04 & $<1$ \\
\hline Women in Management Review & 04 & $<1$ \\
\hline British Journal of Industrial Relations & 04 & $<1$ \\
\hline Construction Management and Economics & 03 & $<1$ \\
\hline British journal of Management & 03 & $<1$ \\
\hline Administrative Science Quarterly & 01 & $<1$ \\
\hline Group and Organization Management & 01 & $<1$ \\
\hline Journal of Management Studies & 01 & $<1$ \\
\hline
\end{tabular}

Percentages are based on total number of studies $(N=535)$.

${ }^{a}$ Previously titled, Journal of Occupational Behavior

${ }^{\mathrm{b}}$ Previously titled Journal of Occupational Psychology 
By scrutinising those articles, the following themes were identified in the specified period, from 1980 to the present: directions of work family conflict, consequences of work family conflict, organisational responsiveness to work family issues, predictors of work family conflict, influences of demographic variables on work family conflict, methodological aspects of work family conflict. Other aspects are included under additional themes.

\section{Directions of Work family conflict}

Although work family conflict is anchored in role theory, which was developed in 1964 (Greenhaus and Beutell, 1985), the conceptualisation of work family conflict between 1980 and the present has changed. In the 1980s, work family conflict was considered as a 'unidimensional construct' by many researchers (e.g., Kopelman et al., 1983; Cooke and Rousseau, 1984; Bedeian et al., 1988). However, during the 1990s, work family conflict was as two distinct constructs: 'work to family conflict' and 'family to work conflict' (e.g., Gutek et al., 1991; Frone et al., 1992; Williams and Alliger, 1994; Kelloway et al., 1999; Haines et al., 2013; Allen et al., 2013). In 2000, Carlson et al. clearly spelt out two distinct constructs of work family conflict with three forms, leading to a six dimensional model of work family conflict: work to family conflict including three forms (time based, strained based and behavioural based), and family to work conflict including three forms (time based, strained based and behavioural based). In addition, $\mathrm{Lu}$ et al. (2006) proffered another form of work family conflict as 'worry based conflict', which may be more salient than behaviour-based conflict in modern industrial society. They argued that persistently high unemployment rates, increasing living costs, marital distress, and parental stress may damage the stability of family life causing worries that interfere with work ( $\mathrm{Lu}$ et al, 2006). In the contemporary scenario, many research scholars assert that both directions of work family conflict need to be examined to fully understand the work family interface (e.g., Carlson et al., 2000; Anafarta, 2010).

\section{Consequences of work family conflict}

Conflicts between employees' work and non-work responsibilities have received considerable attention as researchers have consistently demonstrated the negative consequences for both the individual and the organization (e.g., Aryee, 1992; Frone et al., 1992; Thomas and Ganster, 1995). For example, many employees are not willing to work more hours as this reduces the time available to them to fulfil their family roles because anxiety and fatigue caused by strain from one role are likely to make it difficult to perform in another role (e.g., Frone et al., 1997). The possible outcomes of work family conflict can be classified into physical outcomes (e.g. poor appetite, headache, stomach upset, fatigue, hypertension), psychological outcomes (e.g. depression, lower marital satisfaction, psychological distress, lower life satisfaction), behavioural outcomes (e.g. heavy drinking, cigarette use, anger), and work related outcomes (e.g. lower job satisfaction, absenteeism, tardiness and poor work-related role performance) (e.g., Schmidt et al., 1980; Greenhaus and Beutell, 1985; Bedeian et al., 1988; Aryeel, 1993; Aryee and Luk,1996; Frone et al., 1997; Chiu, 1998; Kossek and Ozeki, 1998; Aryee et al.,1999; Burke and Greenglass, 1999; Allen et al., 2000; Fu and Shaffer, 2001; Parasurman and Simmers, 2001; Bruck et al., 2002; Ng et al., 2002; 
Stoeva et al., 2002; Grandey et al., 2005; Foley et al., 2005; Hang-Yue et al., 2005; Boyar and Mosley, 2007; Anderson et al., 2008; Lu et al., 2008; Hsu et al., 2010; Wang et al., 2010; Rathi and Barath, 2013; Glaveli et al., 2013). In addition, work family conflict is related to greater turnover intention (e.g., Greenhaus et al., 2001), lower perceived career success and satisfaction (e.g., Peluchette, 1993; Martins et al., 2002) and levels of burnout (e.g., Burke, 1988).

On the other hand, in 1987, Wiley reported that greater work family conflict is related to greater job involvement and affective organizational commitment, whereas Frone (2000) found that work family conflict is positively related to anxiety disorders, mood disorders, and substance abuse disorders, and his results also showed that the relationship between family to work conflict and anxiety disorders was stronger among men than women. Greenhaus, Parasuraman and Collins (2001) argued that actual turnover and turnover intention are lower among individuals who are less involved in their careers. A limited number of studies have examined the mediators of the role of work family conflict between both work to family conflict and family to work conflict, and life satisfaction (e.g., Kopelman et al., 1983), between both role overload and role conflict with job burnout (Bacharach et al., 1991), between job time demands and psychological strain outcomes (e.g., Major et al., 2002), and between work expectations, work conflict, job involvement, and family involvement with both quality of work and quality of family life (Higgins et al., 1992).

\section{Organizational responsiveness at work family issues}

Since work family conflict is associated with severe negative consequences for both organisation and family, organisational responsiveness to work family issues is extremely important. It is related to flexible work options (e.g., Milliken et al., 1998; Baltes et al., 1999), organisational support such as such temporal flexibility, operational flexibility, and supportive supervision (e.g., Clark , 2001; Allen, 2001), a compressed working week (e.g. Baltes et al, 1999), financial work family benefits (e.g., Milliken et al., 1998), informal working accommodation such as rearranging work schedules, taking work home, bringing kids to work (e.g., Behson, 2002), childcare (e.g., Goff et al., 1990; Kossek and Nichol, 1992), eldercare assistance (e.g., Wagner and Hunt, 1994; Goodstein, 1995), telecommuting (e.g., Bailey and Kurland, 2002), flexible career paths (e.g., Honeycutt and Rosen,1997), and the adoption of various strategies such as avoidance strategies (e.g., Goodstein, 1994). In 1995, Grover and Crooker (1995) examined the effects of four work family practices: flexible hours/ schedules; information about childcare assistance; assistance with childcare costs; and maternity/paternity leave.

Most of the research concurred that organisational responsiveness was associated with increased job satisfaction (e.g., Clark, 2001; Allen, 2001), lower work family conflict (e.g., Allen, 2001), lower turnover intention (e.g., Allen, 2001), higher organisational commitment (e.g., Allen, 2001), higher organisational performance (e.g., Perry-Smith and Blum, 2000), higher work and family functioning (e.g., Clark, 2001), and stronger profit-sales (e.g., Perry-Smith and Blum, 2000), and overall, it lessened the negative effect of work family conflict (e.g., Behson, 2002). In contrast, some of the studies have explored the influence of 
factors affecting the adoption of work family conflict policies and programmes such as structural factors, employers' beliefs, and industry factors (e.g., Milliken et al., 1998). However, reconciliation policies are extremely uneven across the European welfare states and such policies have to be implemented on the basis of pre-existing policies and cultural frames within each country (e.g., Cousins and Tang, 2004). Poelmans and Sahibzada (2004) claimed that research on the actual implementation of work family policies seems timely and necessary.

\section{Predictors of work family conflict}

Predictors of work family conflict can be categorised into work related predictors and family related predictors.

\section{Work related predictors}

Numerous studies found that working longer hours or longer days can seriously boost work family conflict (e.g., Shamir, 1983; Greenhaus et al., 1987; Carlson and Perrewe, 1999; Grzywacz and Marks, 2000; Nielson et al., 2001; Fagan, 2001; MacInnes, 2005; Boyar et al., 2008; Russell et al., 2009; Allen and Finkelstein, 2014). Moreover, work family conflict was found to be predicted by greater work demands (e.g., Yang et al., 2000), a greater time commitment to work (e.g., Parasurman and Simmers, 2001), rotating shifts (e.g., Shamir, 1983), higher organisational loyalty (e.g., Tenbrunsel et al., 1995), greater autonomy at work (e.g., Parasurman and Simmers, 2001), inequity rewards at work (e.g., Greenhaus et al., 1987), and working weekends (e.g., Shamir, 1983).

Cousins and Tang (2004) conducted a study in the Netherlands, Sweden and the UK, to find out about working time flexibility and the experience of work and family conflict. Working hours are different in the three different countries. Males' working hours are 40.5 hours, 41.7 hours and 43.5 hours per week respectively in the Netherlands, Sweden and the UK. Correspondently, females' working hours are 26.0 hours, 36.5 hours and 29.1 hours per week respectively. It is obvious that the gap between men's and women's average working hours is much greater. Moreover, national newspapers in the UK carry stories that working long hours damages workers' family lives (e.g. Guardian, November 2000; Financial Times, September 2001; Sunday Times, January 2002 cited in White et al., 2003). However, in contrast, studies revealed that a supportive organisational culture, supervision, mentoring, family sensitive supervision, work flexibility and collective socialisation ameliorate work family conflict (e.g., Carlson and Perrewe, 1999; Nielson et al., 2001; Clark, 2002).

\section{Family related predictors}

Several studies found that a number of family related factors are closely associated with work family conflict. Children at home (e.g., Carlson, 1999; Grzywacz and Marks, 2000), family support and number of dependents (e.g., Carlson and Perrewe, 1999; Grzywacz and Marks, 2000), family disagreements (e.g., Williams and Alliger, 1994; Carlson and Perrewe, 1999; Grzywacz and Marks, 2000), childcare (e.g., Fox and Dwyer, 1999), higher involvement in family (e.g., Carlson and Perrewe, 1999), and greater time demands on family (e.g., Carlson and Perrewe, 1999; Yang et al., 2000) were found to be predictors of work family conflict. 


\section{Demographic variables on work family conflict}

A certain number of studies have explored differences in experiences of work family conflict between men and women. The findings of studies on work family conflict that compare the experiences of men and women are not consistent with each other. Some studies found that women report more conflict between work and home than men (e.g., Loerch et al., 1989; Gutek et al., 1991; Lundberg et al., 1994; Nielson et al., 2001) whereas others found that men and women report similar levels of conflict (e.g., Eagle et al., 1997; Emslie et al., 2004; Winslow, 2005). In contrast, some of the research revealed that men experience a higher level of work family conflict than women (e.g., Parasurman and Simmers, 2001). Furthermore, there have been studies that have failed to find gender differences in the experience of work family conflict (e.g., Duxbury and Higgins, 1991; Frone et al., 1992; Eagle et al., 1997; Grandey and Cropanzano, 1999). In those studies, different experiences were found to be due to work related factors (e.g, working hours), family related factors (e.g., number of dependents), demographic factors (e.g., education) and other methodological aspects. In 1997, Loscocco, in his qualitative study, reported that men experience more work to family conflict whereas women experience more family to work conflict, if they have young children. Moreover, Duxbury and Higgins (1991) found that work family conflict is strongly related to hindering quality of family life more for men than women. Interestingly, Hammer et al. (1997) examined the effects of work family conflict on dual earner couples. Their results show that regardless of gender, work family conflict is related to higher work involvement and less schedule flexibility. However, greater family involvement is related to greater work family conflict for women but not men.

On the other hand, there is a relationship between gender role perspective and work family conflict. Gender role perspective states that work is for men and domestic responsibilities and housekeeping are for women (e.g., Gutek et al., 1991). That is, 'men are the breadwinners and women are the homemakers'. Therefore, researchers have hypothesised that work is more important for men and family is more important for women. Thus, family related factors interfere more with work for women than for men, and work related factors interfere more with family for men than for women (e.g., Frone et al., 1997). Nowadays, women may be more likely to manage the primary family responsibilities along with work responsibilities. Therefore, women may be more likely to experience family to work conflict. In the contemporary world, many researchers on work family conflict either ignore gender or take it for granted. In 2004, Gerson argued that work and family should be examined through a gender lens.

Moreover, a number of previous studies have investigated experiences of work family conflict among men and women of different ages and status (e.g., Chandola et al., 2004; Emslie et al., 2004). Recently, Emslie and Hunt (2009) conducted semi-structured interviews specifically with middle-aged men and women (aged 50 to 52 years). They found that the women engaged in a variety of roles (despite having no young children at home) and thus experienced more work family conflict than men. Age is another demographic factor that has been studied in work family research. Unfortunately, the effect of age on the experience of work family conflict has not been studied adequately. Some studies did not find any 
significant relationship between age and work to family conflict or family to work conflict (e.g., Frone, Russell and Cooper, 1997). Also, Grzywacz and Marks (2000) found that younger men reported more work to family conflict and family to work conflict than older men. Their results indicated that younger women reported more family to work conflict than older women. In addition to gender and age, a few studies conducted in the past have established a positive linkage between pay level and work family conflict (e.g., Boyar et al., 2008; Bhave et al., 2013). Moreover, one of the studies also examined the characteristics of education and income. However, the results suggest that the two factors do not substantially influence work family conflict (Frone et al., 1992)

\section{Methodological theme}

A number of work family conflict measures have been developed by researchers at different times. The majority of measures recognise the bidirectional nature of the conflict. The most consistently cited measure in the 1980s was Kopelman, Greenhaus and Connolly's measure (1983), whereas in the 1990s it was Frone et al. (1992) measure. However, in practice, Netemeyer et al. (1996) 10- items measure of work family conflict, and Carlson et al. (2000) multidimensional measure of work family conflict have been popular recently (e.g., O'Driscoll et al., 2003; Allen and Armstrong, 2006; Spector et al.,2007; Matthews et al., 2010; Halbesleben et al., 2012; Liu, et al., 2013; Cowlishaw et al., 2014). Nonetheless, the work family conflict measures of Burke et al. (1979), Gutek et al. (1991), Hill et al. (2003), Thompson et al. (1999), Greenhaus et al. (2001) are also frequently cited. Therefore, several standard measures of work family conflict now exist. Notwithstanding those above, most recently, Matthews et al. (2010) developed an abbreviated version of Carlson et al. (2000) multidimensional measure of work family conflict, consisting of six items.

Most of the work family conflict research has been conducted in the United States, Australia, the United Kingdom and Ireland, and Western Europe. Up to 2006, just 5\% of the studies had been conducted in Asia (Chang et al., 2009). However, more recently, Chinese researchers have created more impetus for broadening work family research in Asia (e.g., Choi, 2008). There is a paucity of research in cross-national and cross-cultural studies. The cross-national studies that have been undertaken have compared data from two or more similar countries (e.g. Australia and the United Kingdom: e.g., Harley and Whitehouse, 2001). A few cross cultural studies provide exemplars for future research (e.g., Joplin et al., 2003; Hill et al., 2004; Lu et al., 2010).

\begin{tabular}{lc}
\hline Categorv & Number of Articles \\
\hline Single country & 513 \\
Cross cultural studies & 15 \\
Cross national studies & 07 \\
\hline
\end{tabular}

Cross cultural studies of work family issues address not only the problems faced in diverse regions themselves, but also the greater variation in political, economic, cultural and employment variables than those in single country studies, and thus they provide important insights into hypothesized relationships between the phenomena investigated (Chang et al., 
2009).

\section{Additional themes}

Numerous studies have been carried out across the work family conflict sphere with divergent perspectives. Several studies found moderating and mediating effects on the relationship between job stress, work family conflict, burnout and family functioning. For example, lack of household support and having children under the age of 13 were found to moderate the relationship between job characteristics and family functioning (e.g., Hughes and Galinsky, 1994). Staines and Pleck (1986) found that schedule flexibility moderated the negative effect of non-standard work schedules on family life. Westman and Etzion (1995) studied the crossover effects of burnout between husband and wife, and their findings supported their prediction that a husband's burnout was positively related to his wife's burnout and vice versa. Beutell and Brenner (1986) studied gender differences in work values. Security, prestige, advancement, and challenge were associated with men, whereas work environment, learning and development, independence, cultural and aesthetic interests, and making a social contribution through work were associated with women. In 1998, Barling and colleagues uniquely examined the impact of parental job stress on children's work attitudes and beliefs. Their results showed that perceptions of a father's job insecurity influenced children's own work beliefs and attitudes, whereas the mother's job insecurity was not related. At the cultural level, Yang et al. (2000) found that American employees reported greater family demands than Chinese employees, and consequently family demands had a greater effect on work family conflict among American employees. However, work demands were greater for Chinese employees and they had a greater effect on work family conflict among Chinese workers.

Besides the known arena of work family conflict, the unknown arena of work family conflict has been subsumed into the following themes for discussion.

\section{Regional gap- a theoretical cultural perspective}

Most of the work family conflict research has been conducted in more affluent countries in the West whereas relatively few work family studies have surfaced from less affluent developing countries, or from nations the East (e.g., Joplin et al., 2003; Hassan et al., 2010). Western countries tend to have cultures that value individualism (Yang, et al., 2000; Hofstede et al., 2010), and many have governmental and corporate work family resources and policies to support individuals in their aspirations to be successful in both their occupational and family lives. They also tend to espouse the value of gender equality. In contrast, Eastern countries tend to have cultures that value collectivism (Yang, et al., 2000; Hofstede et al., 2010) and their way of viewing work and family life is different. To put this in a simple way, individualists 'live to work' whereas collectivists 'work to live' (Hassan et al., 2010). Thus, in a collectivistic culture, in order attain meaningful life and happiness, family welfare is given utmost importance (Lu et al., 2006). However, almost all of the work family conflict theory is based purely on Western studies and cultures. It is questionable whether theories, models and findings of work family conflict research carried out in Western countries are valid in other settings (e.g., Poelmans, 2003; Spector et al. 2004). 
The nature and magnitude of WFC might be different in collectivist cultural nations owing to cultural factors (e.g. Hang-Yue et al., 2005; Spector et al., 2007). For instance, the extended family structure, work place relationship (paternalistic role and emotional nature), large power distance, family culture (patriarchal where men's "headship" and women's "submission") and sensitiveness to interpersonal problems and other interpersonal conflicts are peculiar to collectivist cultures (e.g., Mesquita, 2001; Spector et al., 2007; Hofstede et al., 2010), and potentially influence WFC. For example, emotion in collectivist cultures is a relational phenomenon (Mesquita, 2001) and employees are often afraid of disagreeing with their superiors, which reflects the state of relationship. Consequently, employees tend to think about or be preoccupied with work matters while they are at home and this can encroach on the performance of their family role. Based on these cultural factors and the seminal studies of Clark (2000), Ashforth et al. (2000) and Carlson and Frone (2003), this scholarship proposes a new under-researched dimension of psychological based WFC as a fourth dimension of work family conflict, which explains how thinking about/preoccupation with the performance of a work role will distract individuals in their family role or the family role will affect the work role in a collectivist cultural nation.

Moreover, the behavioural based work family conflict dimension was discarded in many recent studies (e.g., Lu et al., 2006; Hoobler et al., 2009; Powell and Greenhaus, 2010; Griggs et al., 2013; Kailasapathy et al., 2014). It might be plausible that nowadays, in the cut-throat and cutting edge business milieux, employee-employer-customer relationships are much more complaisant and involve a more deferential approach than ever before and ipso facto, some of the theories developed a couple of decades do not hold water today. Thus they need to be redefined across many countries.

In 2008, Choi studied the effects of work and family demands on the life stress of Chinese employees. His results suggested that both work and family demands are related to life stress and that family demands seemed to have a stronger association with life stress than work demands. His study contributed to the literature by demonstrating a relationship between family and work demands in a developing country. However, he argued that the findings of this study may not be generalisable to all other developing countries. This may be because of the magnitude of the factors influencing the work family context, for example political, economical, and cultural factors and so on. This is supported by Hofstede et al. (2010). They explained the cultural dimensions by ranking them for different countries; for example the masculinity dimension is ranked 56 for India, but for Pakistan it is ranked 50. Therefore, in different cultures employees' responses to interpersonal conflicts are vulnerable in the work and family domains. Therefore, this study calls for future research to capture the varying dynamics of the experience of work family conflict in exogenous countries.

In addition, Lu et al. (2010) recommended that both culture-general and culture-specific effects should be taken into consideration in designing future work family conflict research and family friendly managerial practices. Thus, in a shrinking world, it is important to keep in mind that not all individuals in a collectivist society will be collectivists and vice versa. Therefore, there is an unexplored gap in work family conflict research in exploring similarities and differences in Eastern countries so that Asian work family conflict theory can 
be established.

\section{Measurement gap}

There is another vital gap in the measurement of work family conflict. The existing work family conflict questionnaires (e.g., Netemeyer et al., 1996; Carlson et al., 2000) were developed in the Western counties. However, in the absence of a well validated scale based on Eastern cultures, most researchers in Eastern cultures randomly chose a questionnaire from a pool of questionnaires developed in the West rather developing or adapting to their own culture. Many research scholars have argued that there is a problem associated with using the same questionnaire in a cross cultural study as it has been developed in another culture (e.g., Hassan et al., 2010). Since there may be different factors influencing work family conflict, the development of a work family conflict questionnaire to represent Eastern culture is of paramount importance and still represents a gap.

\section{Gap in Cross cultural studies}

In 2007, McDonald, Burton and Chang reviewed the sampling choices in 245 empirical work life balance papers published in peer reviewed journals between 1987 and 2006. They suggested that work family balance research needs to be expanded in non industrialised countries with a greater emphasis on cross-cultural comparisons of the phenomena. Many researchers in the West have suggested that work family conflict research in the East clearly needs more systematic investigations of the cultural differences to see whether work family conflict is culture specific or whether it cuts across cultural boundaries. Therefore, it is important to measure the cultural values of the people in conducting work family conflict research.

\section{Gap in organisational responsiveness / transferability of work family conflict policies}

No studies have been carried out to identify the transferability of work family conflict policies and practices from one culture to another. For example, extended family is a unique feature of collectivistic cultures. Most Western researchers speak about the childcare and eldercare policies of organisations (e.g., Goff et al., 1990; Wagner and Hunt, 1994; Goodstein, 1995). However, this may not be the best solution to alleviate work family conflict in collectivistic cultures as there is greater family support in collectivist culture due to the extended family members living in the household, and sharing household chores, childcare etc (Agarwala et al., 2014). Therefore, there is a gap in finding organisational responsiveness to the work family sphere especially in developing/collectivistic countries. Of late, Griggs et al. (2013) have supported previous studies in an examination of the importance of extended family members in work family studies and opined that they were not aware of any published studies investigating extended family support and work family conflict in collectivist cultures.

\section{Gap in changing environmental factors}

Over the next decades it will be expected that there will be more engagement with work family policy because of environmental factors like economic recession (e.g., Hassan et al., 
2010). The answerable question of 'which country in the world is stable' is becoming intriguing. Persistently high unemployment rates, increasing living costs, marital distress, and parental stress may damage the stability of family life, causing worries that interfere with work (Lu et al, 2006). On the other hand, information technology plays a big role in the way that people are doing things both at work and in their families. Therefore, the factors determining work family conflict 30 years ago may not be relevant now. Thus, there is gap in examining the factors that determine work family conflict at the macro, micro and meso levels.

\section{Gap in testing existence of gender role theory}

Related to environmental changes and national differences, there is the intriguing question of 'whether role theory is still valid' in a collectivist culture. Gender role theory mostly assumes the 'men are the breadwinners and women are the homemakers' family model. In the contemporary world, women become more educated, go to work, and look after their kin and they can act independently. Therefore, has the major role of the women been changing in the past two decades? Or do women only support the uplifting of the living standards of their family particularly in developing countries? An overarching fact is that researchers should refine gender role theory in accordance with the new era.

\section{Implications and Conclusion}

Research on work family conflict is criticised by many research scholars for testing previously discussed relationships rather than developing new models or concepts (Bardoel et al., 2008) and far less exploratory research was conducted between 1980 and 2003 (Casper et al. 2007). In line with this argument, this research provides a starting point for academic research scholars to understand and assess known and unknown areas of work family conflict research during the past 30 years. Therefore, this present study serves as a springboard for future studies and theory building on the interaction between the work and family domains. Furthermore, this research urges policy makers, practitioners and members of organisations to collaborate in order to identify the best mechanism to balance work and family in the contemporary world. More specifically, research has supported that work family conflict has its own flavour across different countries and cultures. Nowadays, people's movement from country to country with the view to working in a host country, international recruitment, and migration are common features surrounding human beings. Therefore, this study alerts organisational policy makers to think about the cultural differences of people working within the same organisation. In sum, this research encourages the development and dissemination of the work family sphere towards bridging the gap between theory and practice in different scenarios.

Although this research has reviewed a large number of research papers published during the last three decades, it acknowledges several limitations. Firstly, this research focused merely on journal articles and not published books, conference papers, colloquium papers or any other sources. Therefore, the findings and conclusions are strictly confined to research articles published in journals. However, other scholarly works / materials may have some valuable insights into work family conflict research. Secondly, published research papers not 
written in English were excluded from analysis and the exclusion of other languages is known as "Tower of Babel Bias' (Gregoire et al., 1995).

All in all, there is a dearth of systematic reviews on work family conflict literature to date. The primary aim of this study was to answer the question of what is missing from the research agenda, and what research needs to be done by systematically reviewing the existing literature over the past 30 years. Research on work family conflict has revealed that work and family lives are interdependent and flow in both directions; there is work to family conflict and family to work conflict. The identified seven themes during the past three decades were systematically explained with utmost effectiveness. Profoundly, this research has outlined existing gaps in the literature and the agenda for the future was scrupulously discussed. Therefore, the present study serves as a springboard for future studies.

\section{References}

Adams, G.A., King, L.A. \& King, D.W. (1996). Relationships of job and family involvement, family social support, and work-family conflict with job and life satisfaction. Journal of Applied Psychology, 81(4), 411-420. http://dx.doi.org/10.1037/0021-9010.81.4.411

Agarwala, T., Arizkuren-Eleta, A., Del Castillo, E., Muñiz-Ferrer, M. \& Gartzia, L. (2014). Influence of managerial support on work-life conflict and organizational commitment: an international comparison for India, Peru and Spain. The International Journal of Human Resource Management, 25(10), 1460-1483. http://dx.doi.org/10.1080/09585192.2013.870315

Allen, T. D. (2001). Family-supportive work environments: The role of organizational perceptions. Journal of Vocational Behavior, 58 (3), 414-435. http://dx.doi.org/10.1006/jvbe.2000.1774

Allen, T.D. \& Armstrong, J. (2006). Further Examination of the Link Between Work Family Conflict and Physical Health The Role of Health-Related Behaviors. American Behavioral Scientist, 49 (9), 1204-1221. http://dx.doi.org/10.1177/0002764206286386

Allen, T. D. \& Finkelstein, L. M. (2014). Work-Family Conflict Among Members of Full-Time Dual-Earner Couples: An Examination of Family Life Stage, Gender, and Age. Journal of occupational health psychology, 19(3), 376-384. http://dx.doi.org/10.1037/a0036941

Allen, T. D., Herst, D. E., Bruck, C. S. \& Sutton, M. (2000). Consequences associated with work to family conflict: A review and agenda for future research. Journal of Occupational Health Psychology, 5 (2), 278-308. http://dx.doi.org/10.1037/1076-8998.5.2.278

Allen, T.D., Johnson, R.C., Kiburz, K.M. \& and Shockley, K.M. (2013). Work-family conflict and flexible work arrangements: Deconstructing flexibility. Personnel Psychology, 66 (2), 345-376. http://dx.doi.org/10.1111/peps.12012

Anafarta, N. (2010). The Relationship between Work-Family Conflict and Job Satisfaction: A Structural Equation Modeling (SEM) Approach. International Journal of Business and Management, 6 (4), 168-177. http://dx.doi.org/10.5539/ijbm.v6n4p168 
Anderson, S. E., Coffey, B. S., Liu, Y. \& Zhao, S. (2008). Employees in Chinese enterprises: Antecedents and outcomes of work-family balance. Chinese Economy, 41(5), 22-50. http://dx.doi.org/10.2753/CES1097-1475410502

Aryee, S. (1992). Antecedents and outcomes of work-family conflicts among married professional women: evidence from Singapore. Human Relations, 45(8), 813-837. http://dx.doi.org/10.1177/001872679204500804

Aryee, S. \& Luk, V. (1996). Work and nonwork influences on the career satisfaction of dual-earner couples. Journal of Vocational Behavior, 49(1), 38-52. http://dx.doi.org/10.1006/jvbe.1996.0032

Aryee, S., Luk, V., Leung, A. \& Lo, S. (1999). Role stressors, interrole conflict, and well-being: The moderating influence of spousal support and coping behaviors among employed parents in Hong Kong. Journal of Vocational Behavior, 54 (2), 259-278. http://dx.doi.org/10.1006/jvbe.1998.1667

Aryeel, S. (1993). Dual-earner couples in Singapore: An examination of work and nonwork sources of their experienced burnout. Human relations, 46 (12), 1441-1468. http://dx.doi.org/10.1177/001872679304601205

Ashforth, B.E., Kreiner, G.E. \& Fugate, M. (2000). All in a day's work: Boundaries and micro role transitions. Academy of Management review, 25 (3), 472-491. http://dx.doi.org/10.5465/AMR.2000.3363315

Bacharach, S. B., Bamberger, P. \& Conley, S. (1991). Work-home conflict among nurses and engineers: Mediating the impact of role stress on burnout and satisfaction at work. Journal of Organizational Behavior, 12 (1), 39-53. http://dx.doi.org/10.1002/job.4030120104

Bailey, D.E. \& Kurland, N. B. (2002). A review of telework research: findings, new directions, and lessons for the study of modern work. Journal of organizational behavior, 23 (4), 383-400. http://dx.doi.org/10.1002/job.144

Baltes, B. B., Briggs, T.E., Huff, J.W., Wright, J.A. \& Neuman, G.A. (1999). Flexible and compressed workweek schedules: A meta-analysis of their effects on work related criteria. $\begin{array}{llllll}\text { Journal of } & \text { applied } & \text { psychology, } & 84 & \text { (4), }\end{array}$ http://dx.doi.org/10.1037/0021-9010.84.4.496

Bardoel, E.A., De Cieri, H. \& Santos, C. (2008). A review of work life research in Australia and New Zealand. Asia Pacific Journal of Human Resources, 46 (3), 316-333. http://dx.doi.org/10.1177/1038411108095762

Barling, J., Dupre, K. E. \& Hepburn, C. G. (1998). Effects of parents' job insecurity on children's work beliefs and attitudes. Journal of Applied Psychology, 83 (1), 112-118. http://dx.doi.org/10.1037/0021-9010.83.1.112

Bedeian, A. G., Burke, B. G. \& Moffett, R. G. (1988). Outcomes of work-family conflict among married male and female professionals. Journal of Management, 14(3), 475-491. http://dx.doi.org/10.1177/014920638801400310 
Behson, S. J. (2002). Coping with family-to-work conflict: The role of informal work accommodations to family. Journal of Occupational Health Psychology, 7 (4), 324-341. http://dx.doi.org/10.1037/1076-8998.7.4.324

Beutell, N. J. \& Brenner, O. C. (1986). Sex differences in work values. Journal of Vocational Behavior, 28 (1), 29-41. http://dx.doi.org/10.1016/0001-8791(86)90037-0

Bhave, D.P., Kramer, A. \& Glomb, T.M. (2013). Pay satisfaction and work-family conflict across time. Journal of Organizational Behavior, 34 (5), 698-713. http://dx.doi.org/10.1002/job.1832

Blaikie, N. (2007), Approaches to social enquiry, $2^{\text {nd }}$ edn, Polity press, Cambridge.

Boyar, S.L. \& Mosley Jr, D.C. (2007). The relationship between core self-evaluations and work and family satisfaction: The mediating role of work-family conflict and facilitation. Journal of Vocational Behavior, $71 \quad$ (2), 265-281. http://dx.doi.org/10.1016/j.jvb.2007.06.001

Boyar, S.L., Maertz Jr, C.P., Mosley Jr, D.C. \& Carr, J.C. (2008). The impact of work/family demand on work-family conflict. Journal of Managerial Psychology, 23 (3), 215-235. http://dx.doi.org/10.1108/02683940810861356

Burke, R. J. (1988). Some antecedents and consequences of work-family conflict. Journal of Social Behavior and Personality, 3 (4), 287-302.

Bruck, C.S., Allen, T.D. \& Spector, P.E. (2002). The relation between work-family conflict and job satisfaction: a finer-grained analysis., Journal of Vocational Behavior, 60 (3), 336-353. http://dx.doi.org/10.1006/jvbe.2001.1836

Burke, R. J. \& Greenglass, E. R. (1999). Work-family conflict, spouse support, and nursing staff well-being during organizational restructuring. Journal of Occupational Health Psychology, 4 (4), 327-336. http://dx.doi.org/10.1037/1076-8998.4.4.327

Burke, R.J., Weir, T., DuWors, J. \& Richard E. (1979). Type A Behavior of Administrators and Wives' Reports of Marital Satisfaction and Well-Being. Journal of Applied Psychology, 64(1), 57-65. http://dx.doi.org/10.1037/0021-9010.64.1.57

Carlson, D. S. (1999). Personality and role variables as predictors of three forms of work-family conflict. Journal of Vocational Behavior, 55(2), 236-253. http://dx.doi.org/10.1006/jvbe.1999.1680

Carlson, D.S. \& Frone, M.R. (2003). Relation of behavioral and psychological involvement to a new four-factor conceptualization of work-family interference. Journal of business and psychology, 17 (4), 515-535. http://dx.doi.org/10.1023/A:1023404302295

Carlson, D.S., Kacmar, K.M. \& Williams, L. J. (2000). Construction and Initial Validation of a Multidimensional Measure of Work-Family Conflict. Journal of Vocational Behavior, 56 (2), 249-276. http://dx.doi.org/10.1006/jvbe.1999.1713

Carlson, D. S. \& Perrewe, P. L. (1999). The role of social support in the stressor-strain 
relationship: An examination of work-family conflict. Journal of Management, 25 (4), 513-540. http://dx.doi.org/10.1177/014920639902500403

Casper, W., Eby, Bordeaux, C., L., Lockwood, A. \& Lambert, D. (2007). A Review of Research Methods in IO/OB Work-Family Research. Journal of Applied Psychology, 92 (1), 28-43. http://dx.doi.org/10.1037/0021-9010.92.1.28

Chandola, T., Martikainen, P., Bartley, M., Lahelma, E., Marmot, M., Michikazu, S., Nasermoaddeli, A. \& Kagamimori, S. (2004). Does conflict between home and work explain the effect of multiple roles on mental health? A comparative study of Finland, Japan, and the UK. International Journal of Epidemiology, 33 (4), 884-893. http://dx.doi.org/10.1093/ije/dyh155

Chang, A., McDonald, P. \& Burton, P. (2010). Methodological choices in work-life balance research 1987 to 2006: a critical review. International Journal of Human Resource Management, 21 (13), 2381-2413. http://dx.doi.org/10.1080/09585192.2010.516592

Chiu, R. K. (1998). Relationships among role conflicts, role satisfactions and life satisfaction: Evidence from Hong Kong. Social Behavior and Personality: an international journal, 26 (4), 409-414. http://dx.doi.org/10.2224/sbp.1998.26.4.409

Choi, J. (2008). Work and family demands and life stress among Chinese employees: The mediating effect of work-family conflict. The International Journal of Human Resource Management, 19 (5), 878-895. http://worldcat.org/isbn/9780415457668

Clark, S.C. (2000).Work/family border theory: A new theory of work/family balance. Human relations, 53 (6), 747-770. http://dx.doi.org/10.1177/0018726700536001

Clark, S. C. (2001).Work cultures and work/family balance. Journal of Vocational Behavior, 58 (3), 348-365. http://dx.doi.org/10.1006/jvbe.2000.1759

Clark, S. C. (2002). Employees' sense of community, sense of control, and work/family conflict in Native American organizations. Journal of Vocational Behavior, 61 (1), 92-108. http://dx.doi.org/10.1006/jvbe.2001.1846

Cooke, R. A. \& Rousseau, D. M. (1984). Stress and strain from family roles and work-role expectations. Journal of Applied Psychology, 69(2), 252-260. http://dx.doi.org/10.1037/0021-9010.69.2.252

Corbin, J. \& Strauss, A. (1990). Grounded theory research: Procedures, canons, and evaluative criteria. Qualitative Sociology, 13(1), 3-21. http://dx.doi.org/10.1007/BF00988593

Cousins, C.R. \& Tang, N. (2004). Working time and work and family conflict in the Netherlands, Sweden and the UK. Work, employment and society, 18(3), 531-549. http://dx.doi.org/10.1177/0950017004045549

Cowlishaw, S., Birch, A., McLennan, J. \& Hayes, P. (2014). Antecedents and Outcomes of Volunteer Work-Family Conflict and Facilitation in Australia. Applied Psychology, 63(1), 168-189. http://dx.doi.org/10.1111/apps.12000 


\section{Macrothink}

International Journal of Human Resource Studies ISSN 2162-3058 2015, Vol. 5, No. 2

Drago, R. \& Kashian, R. (2003). Mapping the terrain of work/family journals. Journal of Family Issues, 24(4), 488-512. http://dx.doi.org/10.1177/0192513X0225074

Duxbury, L. E. \& Higgins, C. A. (1991). Gender differences in work-family conflict. Journal of Applied Psychology, 76(1), 60-73. http://dx.doi.org/10.1037/0021-9010.76.1.60

Eagle, B.W., Miles, E.W. \& Icenogle, M.L. (1997). Inter-role conflicts and the permeability of work and family domains: are there gender differences? Journal of Vocational Behavior, 50 (2), 168-184. http://dx.doi.org/10.1006/jvbe.1996.1569

Easterby-Smith, M., Thorpe, R. \& Lowe, A. (2002). Management Research an Introduction, $2^{\text {nd }}$ edn, Sage Publications, Thousand Oaks.

Emslie, C. \& Hunt, K. (2009). Live to Work or Work to Live? A Qualitative Study of Gender and Work-life Balance among Men and Women in Mid-life. Gender, Work and Organization, 16(1), 151-175. http://dx.doi.org/10.1111/j.1468-0432.2008.00434.x

Emslie, C., Hunt, K. \& Macintyre, S. (2004). Gender, work-home conflict and morbidity amongst white-collar bank employees in the UK. International Journal of Behavioral Medicine, 11(3), 127-134. http://dx.doi.org/10.1207/s15327558ijbm1103_1

Fagan, C. (2001). Time, Money, and the Gender Order: Work-orientations and Working-Time Preferences in Britain. Gender, Work and Organization, 8(3), 239-266. http://dx.doi.org/10.1111/1468-0432.00131

Foley, S., Hang-Yue, N. \& Lui, S. (2005). The effects of work stressors, perceived organizational support, and gender on work-family conflict in Hong Kong. Asia Pacific Journal of Management, 22 (3), 237-256. http://dx.doi.org/10.1007/s10490-005-3568-3

Fox, M. L. \& Dwyer, D. J. (1999). An investigation of the effects of time and involvement in the relationship between stressors and work-family conflict. Journal of Occupational Health Psychology, 4 (2), 164-174. http://dx.doi.org/10.1037/1076-8998.4.2.164

Frone, M. R. (2000). Work-family conflict and employee psychiatric disorders: The National Comorbidity Study. Journal of Applied Psychology, 85(6), 888-895. http://dx.doi.org/10.1037/0021-9010.85.6.888

Frone, M.R., Russell, M. \& Cooper, M.L. (1992). Antecedents and outcomes of work-family conflict: Testing a model of the work-family interface. Journal of Applied Psychology, 77 (1), 65-78. http://dx.doi.org/10.1037/0021-9010.77.1.65

Frone, M.R., Russell, M. \& Cooper, M.L (1997). Relation of work family conflict to health outcomes: A four- year longitudinal study of employed parents. Journal of occupational and organizational psychology, 70(4),

325-335. http://dx.doi.org/10.1111/j.2044-8325.1997.tb00652.x 
Fu, C. K. \& Shaffer, M. A. (2001). The tug of work and family: Direct and indirect domain-specific determinants of work-family conflict. Personnel review, 30 (5), 502-522. http://dx.doi.org/10.1108/EUM0000000005936

Gerson, K. (2004). Understanding work and family through a gender lens. Community, Work and Family, 7(2), 163-178. http://dx.doi.org 10.1080/1366880042000245452

Glaveli, N., Karassavidou, E. \& Zafiropoulos, K. (2013). Relationships among three facets of family-supportive work environments, work-family conflict and job satisfaction: a research in Greece. The International Journal of Human Resource Management, 24 (20), 3757-3771. http://dx.doi.org/10.1080/09585192.2013.778317

Goff, S.J., Mount, M.K. \& Jamison, R.I. (1990). Employer supported child care, work family conflict and absenteeism: A field study. Personnel psychology, 43 (4), 793-809. http://dx.doi.org/10.1111/j.1744-6570.1990.tb00683.x

Goodstein, J. D. (1994). Institutional pressures and strategic responsiveness: Employer involvement in work-family issues. Academy of Management Journal, 37(2), 350-382. http://dx.doi.org/10.2307/256833

Goodstein, J. (1995). Employer involvement in eldercare: An organizational adaptation perspective. Academy of Management Journal, 38(6), 1657-1671. http://dx.doi.org/10.2307/256848

Grandey, A. \& Cropanzano, R. (1999). The conservation of resources model applied to work-family conflict and strain. Journal of Vocational Behavior, 54(2), 350-370. http://dx.doi.org/10.1006/jvbe.1998.1666

Grandey, A., Cordeiro,B. \& Crouter, A.(2005). A longitudinal and multi-source test of the work-family conflict and job satisfaction relationship. Journal of Occupational and Organizational Psychology , 78 (3), 1-20. http://dx.doi.org/10.1348/096317905X26769

Greenhaus, J. H., Bedeian, A. G. \& Mossholder, K. W. (1987). Work experiences, job performance, and feelings of personal and family well-being. Journal of Vocational Behavior, 31 (2), 200-215. http://dx.doi.org/10.1016/0001-8791(87)90057-1

Greenhaus, J.H. \& Beutell, N.J. (1985). Sources of conflict between work and family roles. Academy of Management Review, $10 \quad$ 76-88. http://dx.doi.org/10.5465/AMR.1985.4277352

Greenhaus, J. H., Parasuraman, S. \& Collins, K. M. (2001). Career involvement and family involvement as moderators of relationships between work-family conflict and withdrawal from a profession. Journal of Occupational Health Psychology, 6 (2), 91-100. http://dx.doi.org/10.1037/1076-8998.6.2.91

Gregoire, G., Derderian, F. \& Le Lorier, J. (1995). Selecting the Language of the Publications Included in a Meta-Analysis: Is There a Tower of Babel Bias? Journal of Clinical Epidemiology, 48 (1), 159-163. http://dx.doi.org/10.1016/0895-4356(94)00098-B 
Griggs, T.L., Casper, W.J. \& Eby, L.T. (2013). Work, family and community support as predictors of work-family conflict: A study of low-income workers. Journal of Vocational Behavior, 82 (1), 59-68. http://dx.doi.org/10.1016/j.jvb.2012.11.006

Grover, S. L. \& Crooker, K. J. (1995). Who appreciates family-responsive human resource policies: The impact of family-friendly policies on the organizational attachment of parents and non-parents. Personnel Psychology, $48 \quad$ (2), 271-288. http://dx.doi.org/10.1111/j.1744-6570.1995.tb01757.x

Grzywacz, J. G. \& Marks, N. F. (2000). Reconceptualizing the work-family interface: An ecological perspective on the correlates of positive and negative spillover between work and family. Journal of Occupational Health Psychology, 5 (1), 111-126. http://dx.doi.org/10.1037/1076-8998.5.1.111

Gutek, B. A., Searle, S. \& Klepa, L. (1991). Rational versus gender role explanations for work-family conflict. Journal of Applied Psychology, 76 (4), 560-568. http://dx.doi.org/10.1037/0021-9010.76.4.560

Haines, V.Y., Harvey, S., Durand, P. \& Marchand, A. (2013). Core Self-Evaluations, Work-Family Conflict, and Burnout. Journal of Marriage and Family, 75 (3), 778-793. http://dx.doi.org/10.1111/jomf.12026

Halbesleben, J.R., Wheeler, A.R. \& Rossi, A.M. (2012). The costs and benefits of working with one's spouse: A two-sample examination of spousal support, work-family conflict, and emotional exhaustion in work-linked relationships. Journal of Organizational Behavior, 33 (5), 597-615. http://dx.doi.org/10.1002/job.771

Hammer, L. B., Allen, E. \& Grigsby, T. D. (1997). Work-family conflict in dual-earner couples: Within individual and crossover effects of work and family. Journal of Vocational Behavior, 50 (2), 185-203. http://dx.doi.org/10.1006/jvbe.1996.1557

Hang-Yue, N., Foley, S. \& Loi, R. (2005). Work role stressors and turnover intentions: a study of professional clergy in Hong Kong. The international journal of human resource management, 16 (11), 2133-2146. http://dx.doi.org/10.1080/09585190500315141

Harley, B. \& Whitehouse, G. (2001). Women in Part-Time Work: A Comparative Study of Australia and the United Kingdom. Labour and Industry, 12 (2), 33-60. http://dx.doi.org/10.1080/10301763.2001.10669248

Hassan, Z., Dollard, M.F. \&Winefield, A.H. (2010). Work-family conflict in East vs Western countries. Cross Cultural Management: An International Journal, 17 (1), 30-49. http://dx.doi.org/10.1108/13527601011016899

Higgins, C. A., Duxbury, L. E. \& Irving, R. H. (1992).Work-family conflict in the dual-career family. Organizational Behavior and Human Decision Processes, 51 (1), 51-75. http://dx.doi.org/10.1016/0749-5978(92)90004-Q

Hill, E.J., Ferris, M. \& Martinson, V. (2003). Does It Matter Where You Work? A Comparison of How Three Work Venues (Traditional Office, Virtual Office, and Home Office) Influence 
Aspects of Work and Personal/Family Life. Journal of Vocational Behavior, 63 (2) , 220-241. http://dx.doi.org/10.1016/S0001-8791(03)00042-3

Hill, E.J., Yang, C., Hawkins, A.J. \& Ferris, M. (2004). A Cross-Cultural Test of the Work-Family Interface in 48 Countries. Journal of Marriage and Family, 66 (5), 1300-1316. http://dx.doi.org/10.1111/j.0022-2445.2004.00094.x

Hofstede, G., Hofstede, G.J. \& Minkov, M. (2010). Cultures and organizations: Software of the mind, $3^{\text {rd }}$ edn, McGraw-Hill, New York.

Honeycutt, T. L. \& Rosen, B. (1997). Family friendly human resource policies, salary levels, and salient identity as predictors of organizational attraction. Journal of Vocational Behavior, 50 (2), 271-290. http://dx.doi.org/10.1006/jvbe.1996.1554

Hoobler, J.M., Wayne, S.J. \& Lemmon, G. (2009) Bosses perceptions of family-work conflict and women's promotability: Glass ceiling effects. Academy of Management Journal, 52 (5), 939-957. http://dx.doi.org/10.5465/AMJ.2009.44633700

Hsu, B. F., Chen, W. Y., Wang, M. L. \& Lin, Y. Y. (2010). Explaining supervisory support to work-family conflict: The perspectives of guanxi, LMX, and emotional intelligence. Journal of Technology Management in China, 5 (1), 40-54. http://dx.doi.org/10.1108/17468771011032787

Hughes, D. L. \& Galinsky, E. (1994). Work experiences and marital interactions: Elaborating the complexity of work. Journal of Organizational Behavior, 15 (5), 423-438. http://dx.doi.org/10.1002/job.4030150507

Joplin, J.R.W., Shaffer, M.A., Francesco, A. M. \& Lau, T. (2003). The macro environment and work-family conflict: Development of a cross-cultural comparative framework. International Journal of Cross-Cultural Management, 3 (3), 305-328. http://dx.doi.org/10.1177/1470595803003003004

Kailasapathy, P., Kraimer, M.L. \& Metz, I. (2014). The interactive effects of leader member exchange, gender and spouse's gender role orientation on work interference with family conflict. The International Journal of Human Resource Management, 25 (19), 1-21. http://dx.doi.org/10.1080/09585192.2014.891637

Kelloway, E. K., Gottlieb, B. H. \& Barham, L. (1999).The source, nature, and direction of work and family conflict: A longitudinal investigation. Journal of Occupational Health Psychology, 4 (4), 337-346. http://dx.doi.org/10.1037/1076-8998.4.4.337

Kopelman, R.E., Greenhaus, J.H., \& Connolly, T.F. (1983). A Model of Work, Family, and Inter-Role Conflict: A Construct Validation Study. Organizational Behavior and Human Performance, 32 (2), 198-215. http://dx.doi.org/10.1016/0030-5073(83)90147-2

Kossek, E.E. \& Nichol, V. (1992). The effects of on-site child care on employee attitudes and performance. Personnel psychology, $45 \quad$ (3), 485-509. http://dx.doi.org/10.1111/j.1744-6570.1992.tb00857.x 
Kossek, E. E. \& Ozeki, C. (1998). Work-Family conflict, policies, and the job life satisfaction relationship: A review and directions for future organizational behavior-human resources

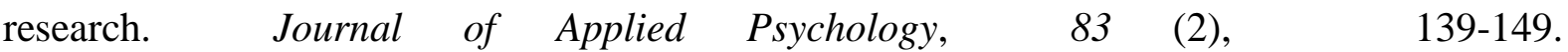
http://dx.doi.org/10.1037/0021-9010.83.2.139

Ling, Y. \& Poweli, G.N. ( 2001). Work-Family Conflict in Contemporary China: Beyond an American-Based Model. International Journal of Cross Cultural Management,1 (3), 357-373. http://dx.doi.org/10.1177/147059580113006

Liu, J., Kwan, H.K., Lee, C. \& Hui, C. (2013). Work-to-Family Spillover Effects of Workplace Ostracism: The Role of Work-Home Segmentation Preferences. Human Resource Management, 52 (1), 75-93. http://dx.doi.org/10.1002/hrm.21513

Loerch, K. J., Russell, J. E. \& Rush, M. C. (1989). The relationships among family domain variables and work-family conflict for men and women. Journal of Vocational Behavior, 35 (3), 288-308. http://dx.doi.org/10.1016/0001-8791(89)90031-6

Loscocco, K. A. (1997). Work-family linkages among self-employed women and men. Journal of Vocational Behavior, 50 (2), 204-226. http://dx.doi.org/10.1006/jvbe.1996.1576

Lu, L., Cooper, C.L., Kao, S. F., Chang,T.T., Allen,T.D., Lapierre, L.M., O'driscoll, M.P., Poelmans,T.A.Y., Sanchez,J.I. \& Spector, P. (2010). Cross-cultural differences on work-to-family conflict and role satisfaction : A Taiwanese-British Comparison. Human Resource Management, 49 (1), 67-85. http://dx.doi.org/10.1002/hrm.20334

Lu, L., Gilmour, R., Koa, S. \& Huang, M. (2006). A cross cultural study of work/family demands, work/family conflict and wellbeing: the Taiwanese vs British. Career development international, 11 (1), 9-27. http://dx.doi.org/10.1108/13620430610642354

Lu, L., Kao, S. F., Chang, T. T., Wu, H. P. \& Cooper, C. L. (2008). Work/family demands, work flexibility, work/family conflict, and their consequences at work: A national probability sample in Taiwan. International Journal of Stress Management, 15 (1), 1-21. http://dx.doi.org/10.1037/1072-5245.15.1.1

Lundberg, U., Mardberg, B. \& Frankenhaeuser, M. (1994). The total workload of male and female white collar workers as related to age, occupational level, and number of children. $\begin{array}{llllll}\text { Scandinavian Journal of } & 35 & \text { (4), }\end{array}$ http://dx.doi.org/10.1111/j.1467-9450.1994.tb00956.x

MacInnes, J. (2005). Work-Life Balance and the Demand for Reduction in Working Hours: Evidence from the British Social Attitudes Survey 2002. British Journal of Industrial Relations, 43 (2), 273-295. http://dx.doi.org/10.1111/j.1467-8543.2005.00355.x

Major, V. S., Klein, K. J. \& Ehrhart, M. G. (2002). Work time, work interference with family, and psychological distress. Journal of Applied Psychology, 87 (3), 427-436. http://dx.doi.org/10.1037/0021-9010.87.3.427 
Martins, L. L., Eddleston, K. A. \& Veiga, J. F. (2002). Moderators of the relationship between work-family conflict and career satisfaction. Academy of Management Journal, 45 (2), 399-409. http://dx.doi.org/10.2307/3069354

Matthews, R.A., Kath, L.M. \& Barnes-Farrell, J.L. (2010). A Short, Valid, Predictive Measure of Work-Family Conflict: Item Selection and Scale Validation. Journal of Occupational Health Psychology, 15 (1), 75-90. http://dx.doi.org/10.1037/a0017443

McDonald, P., Burton, P. \& Chang, A. (2007). Sampling choices in work-life balance research 1987 to 2006: A critical review. Proceedings Managing Our Intellectual and Social Capital: 21st ANZAM 2007 Conference; Sydney, 1-17. http://www.promaco.com.au/2007/anzam/

Mesquita, B. (2001). Emotions in collectivist and individualist contexts. Journal of $\begin{array}{lllll}\text { Personality and } \quad \text { Social } & \text { Psychology, } & 80 & \text { (1), }\end{array}$ http://dx.doi.org/10.1037/0022-3514.80.1.68

Milliken, F. J., Martins, L. L. \& Morgan, H. (1998). Explaining organizational responsiveness to work- family issues: The role of human resource executives as issue interpreters. Academy of Management Journal, 41 (5), 580-592. http://dx.doi.org/10.2307/256944

Netemeyer, R. G., Boles, J. S. \& McMurrian, R. (1996). Development and validation of work-family and family-work conflict scales. Journal of Applied Psychology, 81 (4), 400-410. http://dx.doi.org/10.1037/0021-9010.81.4.400

Ng, C. W., Fosh, P. \& Naylor, D. (2002). Work-family conflict for employees in an East Asian airline: impact on career and relationship to gender. Economic and Industrial Democracy, 23 (1), 67-105. http://dx.doi.org/10.1177/0143831X02231005

Nielson, T. R., Carlson, D. S. \& Lankau, M. J. (2001). The supportive mentor as a means of reducing work-family conflict. Journal of Vocational Behavior, 59 (3), 364-381. http://dx.doi.org/10.1006/jvbe.2001.1806

O’Driscoll, M.P., Poelmans, S., Spector, P.E., Kalliath, T., Allen, T.D., Cooper, C.L. \& Sanchez, J.I. (2003). Family-responsive interventions, perceived organizational and supervisor support, work-family conflict, and psychological strain. International Journal of Stress Management, 10 (4), 326-344. http://dx.doi.org/10.1037/1072-5245.10.4.326

Parasurman, S. \& Simmers, C. A. (2001). Type of employment, work-family conflict and well-being: A comparative study. Journal of Organizational Behavior, 22 (5), 551-568. http://dx.doi.org/10.1002/job.102

Peluchette, J. V. E. (1993). Subjective career success: The influence of individual difference, family, and organizational variables. Journal of Vocational Behavior, 43 (2), 198-208. http://dx.doi.org/10.1006/jvbe.1993.1042

Perry-Smith, J. E. \& Blum, T. C. (2000). Work-family human resource bundles and perceived organizational performance. Academy of Management Journal, 43 (6), 1107-1117. http://dx.doi.org/10.2307/1556339 
Poelmans, S. (2003). The multi-level 'fit' model of work and family. International Journal of Cross Cultural Management, 3 (3), 267-274. http://dx.doi.org/10.1177/1470595803003003001

Poelmans, S., \& Sahibzada, K. (2004). A multi-level model for studying the context and impact of work-family policies and culture in organizations. Human Resource Management Review, 14 (3), 409-431. http://dx.doi.org/10.1016/j.hrmr.2004.10.003

Powell, G.N. \& Greenhaus, J.H. (2010). Sex, gender, and the work-to-family interface: Exploring negative and positive interdependencies. Academy of Management Journal, 53 (3), 513-534. http://dx.doi.org/10.5465/AMJ.2010.51468647

Rathi, N. \& Barath, M. (2013). Work-family conflict and job and family satisfaction: Moderating effect of social support among police personnel. Equality, Diversity and Inclusion: $\quad$ An International Journal, $32 \quad$ (4), 438-454. http://dx.doi.org/10.1108/EDI-10-2012-0092

Russell, H., O'Connell, P.J. \& McGinnity, F. (2009). The Impact of Flexible Working Arrangements on Work-life Conflict and Work Pressure in Ireland. Gender, Work and Organization, 16 (1), 73-97. http://dx.doi.org/10.1111/j.1468-0432.2008.00431.x

Schmidt, N., Colligan, M. J. \& Fitzgerald, M. (1980). Unexplained physical symptoms in eight organizations: Individual and organizational analyses. Journal of Occupational Psychology, 53 (4), 305-317. http://dx.doi.org/10.1111/j.2044-8325.1980.tb00036.x

Shamir, B. (1983). Some antecedents of work-nonwork conflict. Journal of Vocational Behavior, 23 (1), 98-111. http://dx.doi.org/10.1016/0001-8791(83)90062-3

Spector, P. E., Allen, T. D., Poelmans, S. A. Y., Lapierre, L. M., Cooper, C. L., O’Driscoll, M., Sanchez, J.I., Abarca, N., Alexandrova, M., Beham, B., Brough, P., Ferreiro, P. Fraile, G., Qin lu, C., Lu, L., Vela' Zquez, I.M., Pagon, M., Pitariu, H., Salamatov, V., Shima, S., Simoni, A.S., Siu, O. \& Widerszal-bazyl, M. (2007). Cross-national differences in relationships of work demands, job satisfaction and turnover intentions with work-family conflict. Personnel Psychology, 60 (4), 805-835. http://dx.doi.org/10.1111/j.1744-6570.2007.00092.x

Spector, P. E., Cooper, C. L., Poelmans, S., Allen, T. D., O’Driscoll, M. \& Sanchez, J. I (2004). A cross-national comparative study of work/family stressors, working hours, and well-being: China and Latin America vs. the Anglo world. Personnel Psychology, 57 (1), 119-142. http://dx.doi.org/10.1111/j.1744-6570.2004.tb02486.x

Staines, G. L. \& Pleck, J. H. (1986).Work schedule flexibility and family life. Journal of Occupational Behavior, 7 (2), 147-153. http://dx.doi.org/10.1002/job.4030070207

Stoeva, A. Z., Chiu, R. K., \& Greenhaus, J. H. (2002). Negative affectivity, role stress, and work-family conflict. Journal of Vocational Behavior, 60 (1), 1-16. http://dx.doi.org/10.1006/jvbe.2001.1812

Tenbrunsel, A. E., Brett, J. M., Maoz, E. \& Stroh, L. K. (1995). Dynamic and static work-family relationships. Organizational Behavior and Human Decision Processes, 63 (3), 
233-246. http://dx.doi.org/10.1006/obhd.1995.1076

Thomas, L. T. \& Ganster, D. C. (1995). Impact of family-supportive work variables on work-family conflict and strain : A control perspective. Journal of Applied Psychology, 80 (1), 6-15. http://dx.doi.org/10.1037/0021-9010.80.1.6

Thompson, C. A., Beauvais, L. L. \& Lyness, K. S. (1999). When work-family benefits are not enough: The influence of work-family culture on benefit utilization, organizational attachment, and work-family conflict. Journal of Vocational Behavior, 54 (3), 392-415. http://dx.doi.org/10.1006/jvbe.1998.1681

Wagner, D.L. \& Hunt, G.G. (1994). The use of workplace elder care programme by employed caregivers. Research on aging, 16 (1), 69-84. http://dx.doi.org/10.1177/0164027594161005

Wang, M., Liu, S., Zhan, Y. \& Shi, J. (2010). Daily work-family conflict and alcohol use: Testing the cross-level moderation effects of peer drinking norms and social support. Journal of Applied Psychology, $95 \quad$ (2), 377-386. http://dx.doi.org/10.1037/a0018138

Westman, M. \& Etzion, D. (1995). Crossover of stress, strain and resources from one spouse to another. Journal of Organizational Behavior, 16 (2), 169-181. http://dx.doi.org/10.1002/job.4030160207

White, M., Hill, S., McGovern, P., Mills, C. \& Smeaton, D. (2003). High-performance Management Practices, Working Hours and Work-Life Balance. British Journal of Industrial Relations, 41 (2), 175-195. http://dx.doi.org/10.1111/1467-8543.00268

Wiley, D. L. (1987). The relationship between work/nonwork role conflict and job-related outcomes: Some unanticipated findings. Journal of Management, 13 (3), 467-472. http://dx.doi.org/10.1177/014920638701300303

Williams, K., \& Alliger, G. M. (1994). Role stressors, mood spillover, and perceptions of work-family conflict in employed parents. Academy of Management Journal, 37 (4), 837-868. http://dx.doi.org/10.2307/256602

Winslow, S. (2005). Work-family conflict, gender, and parenthood, 1977-1997. Journal of Family Issues, 26 (6), 727-755. http://dx.doi.org/10.1177/0192513X05277522

Yang, N., Chen, C. C., Choi, J., \& Zhou, Y. (2000). Sources of work-family conflict: A Sino-U.S. comparison of the effects of work and family demands. Academy of Management Journal, 43 (1), 113-123. http://dx.doi.org/10.2307/1556390

Young, K., Ashby, D., Boaz, A. \& Grayson, L. (2002). Social science and the evidence-based policy movement. Social Policy and Society, 1 (3), 215-224. http://dx.doi.org/10.1017/S1474746402003068 